\title{
Discourses About the Eligibility of Women on the Moroccan National List:
}

\section{The Gender Foundations of Electoral Inequality}

\author{
Leila Bouasria
}

\begin{abstract}
The introduction of gender quota in Morocco in 2002 has been the subject of much debate revolving around the nomination processes and the ranking orders within the national list. The procedures followed by political parties can uncover other aspects related to gender dynamics. In this article, I set out to understand the processes by which female candidates are selected on the national list. While analyzing the discourses taking place concerning the recruitment process, I will try to pay attention to the gap between discourses and practices. This study allows us to go beyond the approach that looks at gender quotas as a global phenomenon, exploring at the same time the personal views of women who are experiencing the process from inside. How is gender displayed and social structures recreated through this discourse? The analysis of these discourses can contribute significantly to our knowledge of women's political representation and political elite formation. Listening to candidates' views about criteria of selection informs us about the way in which gendered discourses are reproduced and internalized.
\end{abstract}

Keywords: elections, gender, quota, Morocco, national list.

Double-blind peer-reviewed article

Introduction

Several studies have focused on the reasons behind the adoption of gender quotas (Caul, 2001; Krook, 2009), including the way institutional frameworks, quota measures, electoral rules, or political parties' systems influence quota effectiveness (Krook, 2007), the effects of gender quotas on female participation, and the pros and cons of such measures (Bacchi, 2006; Dahlerup, 2006; Krook, 2006; and Murray, 2004). Yet, little empirical research has explored the process of recruitment in the case of reserved quota seats for women.

Research on Morocco shows that the idea of reserved seats, since the introduction of the gender quota in 2002, has caused many conflicts, mostly revolving around the selection and nomination processes, as well as the ranking orders within the national list (Vairel, 2009). ${ }^{1}$ Liddell (2009) has shown how quotas instrumentalize reserved 
seats to consolidate central party decisions and reinforce the idea of parliaments as "patronage machines."

In spite of the substantial increase in the number of women involved in Moroccan politics, political empowerment is dependent on particular circumstances and strategies (Darhour \& Krit, 2009): gender quotas have not achieved their stated goal of transitioning to district seats. This has been proved through seven years of experience and the limited 'sustainability' of women's political representation (Darhour \& Dahlerup, 2013).

When examining public debate, we come across different diagnoses about the principle of national list formation. Some accept the widespread assumption stating that the national list is contrary to the principles of merit as it is based solely on gender. This statement justifies the other discourse looking at political parties' interests, kinship ties, and connections as ranking high on the list of criteria for nomination (Lidell, 2009 , Sater, 2007, 2012). Both discourses rest on the perception that male dominance is reproduced through the system of gender quotas, leading to tokenism.

Quotas are not only a matter of increasing the percentage of women on the lists, but it is a complex process loaded with "symbolic value and importance in terms of the redistribution of power" (Dahlerup, 2008, p. 326). In fact, if quotas are meant to open up closed male-dominated recruitment patterns (i.e., quotas as a fast track), it is crucial to find out the processes by which the 'gatekeepers' allow women in the party organization. How are female candidates selected and by whom? What (formal/informal) criteria are taken into consideration? What are the resources and qualifications that are considered as being decisive? What profiles are privileged in the selection process and which ones are excluded when lists are drawn up? Which ones gain top positions, and why? How are these procedures perceived within the public debate?

This article is an attempt to unveil this "secret garden of nominations" (Krook, 2009). I set out to analyze the procedures followed by political parties to select candidates on the national list in Morocco and look closely at the personal characteristics and qualities of the selected candidates. While trying to answer these different questions, I will try, on the one hand, to pay attention to the gap between discourses and practices, and on the other hand, to be attentive to prominent discourses taking place concerning the recruitment process.

Candidate recruitment on national lists is accused of being hierarchical; criteria for selection have stimulated a fierce debate and are perceived as playing a strategic political role. My argument is that the discourse taking place around the making of the national list might reproduce gender gaps regarding performances at the political level. Polemics raised around 'meritocracy' confirm the fact that higher expectations are placed on women. Gender does not only have a transformative impact on female participation in politics indirectly through gender quotas, but also in other ways, through gendered expectations.

If in a patriarchal society men are viewed as better politicians than women, it is interesting to see how a mechanism of affirmative action, intended to redress socio- 
cultural inequalities, reproduces public discourses viewing women MPs as lacking qualifications, relying on connections, or as playing the role of a token or proxy. This discourse does not only come from men but might also be internalized by women who, in a context characterized by fierce competition, do not only reproduce it, but lose their energy reacting to polemics raised by the nomination process. Therefore, how is gender displayed and social structures recreated through this discourse?

\section{Methodology}

This article draws primarily on semi-structured in-depth interviews conducted with 17 female interviewees from six Moroccan political parties representing different political currents and with two political leaders. At the beginning of the fieldwork, several contacts were made with all political parties that had women MPs elected through the national list during the two last Moroccan parliamentary elections (2007 and 2011), but meetings were refused and sometimes continuously postponed. Through persistence and connections, six out of the 11 political parties presenting a national list were accessed. Five of these parties had women elected on the national list.

The main specificity of this study is that it privileges the empirical approach, by interviewing women candidates who gave their opinions about the national list. Most of the time, through the article, some short biographies (see table 4) of candidates are given in order to shed light on their eligibility to fulfil quotas and the different components that pave the way to acknowledge their voice within political parties. Some of the interviewees are former MPs or nominated among the top candidates on the national list for the 2011 elections. This study concentrates on the national elections of 2011 and was carried out during a period of polemics around the making of national lists (see table 2). Analysis of newspaper articles was also conducted in order to give an idea of the public debates taking place around the elections and to explore the varying discourses on the topic.

\section{The Establishment of Gender Quotas in Morocco}

The gender quota, through a system of 30 reserved seats for women candidates, was introduced in Morocco for the first time during the 2002 legislative elections by memoranda addressed to political leaders by a group of women's organizations. These organizations were created on 26 May 2006 and were working for democratic development and women's access to decision-making positions, namely the "Mouvement pour le Tiers des Sièges élus aux Femmes vers la Parité" (MTSF).

In May 2001, twenty organizations, with a majority of women's associations among them, presented a draft proposal to amend the electoral law, with the purpose of promoting women to positions of responsibility and decision-making. Consequently, a concrete proposal for a gender quota, set at 33 percent with a minimum of 20 percent, was included in debates related to reforms of the electoral system. Indeed, the debates surrounding the organic law concerning the election of members of the House of Representatives were brought before the extraordinary session of the Parliament that ended on April 3, 2002. Article 1 of the Organic Law of the House of Representatives stated that 10 percent of women are to be elected through a national list. This proposal was not in harmony with Article 8 of the Constitution that does not allow any "discrimination" in favour of women since "men and women enjoy 
equal political rights" (el-Messaoudi, 2011). To get around this impasse, a politically tolerated solution was reached through the use of a voluntary quota without any legal provisions to enforce it. Then, in 2002, the parties introduced a gender quota of $10 \%$ as a simple and solemn declaration, without it being officially recognized in the law.

Although this measure was not driven by a legal provision, in 2002, the adoption of a quota on the basis of a national list allowed 35 women to be elected to the House of Representatives - that is 10.77 percent of those elected. Since this measure was not legally founded but only the result of an 'honorary agreement' between political parties, the preservation of this quota during the 2007 elections enhanced a strong willingness to boost women's representation. It should be noted here that, since 2000, the majority of the political parties have adopted quotas of 20 percent to allow women representation in their decision-making bodies.

In 2011, following Organic Law n'27-11 relating to the House of Representatives, the statutory number of members was increased from 325 to 395, with 60 reserved seats for women and 30 for men under 40 years.

This decision was criticized ${ }^{2}$ as being non-compliant with the provisions of Article 19 of the new Constitution ${ }^{3}$ regarding the establishment of a committee for "parity" and the "fight against discrimination towards women" and with Article 6 which states that "the authorities must work to put in place the appropriate conditions that would allow equality, freedom of citizens, and their participation in the political, economic, cultural, and social life." Moreover, this decision was judged as undermining the positive discrimination clearly stated in Article 30 of the new Constitution and against the provisions of the Convention on the Elimination of all Forms of Discrimination against Women (CEDAW) ratified by Morocco in 1979.

The Criteria for Nominating Candidates on the National List It is particularly relevant to note that the public debate presents the national list as a measure to serve certain strategic political objectives. The processes through which women are selected in order to fulfill quota guidelines are very often blamed for being a way that "party gatekeepers" use to deal with internal and external pressures affecting their decisions and choices (Matland, 1998; Karam, 2000). Do political parties adopt strategies that enable them to place women from the national lists in favorable positions that can give them more chances to win? To what extent does the criterion of 'merit' play a role in such decisions?

Regionalism: A Nomination Criterion or a New Political Strategy? The selection process can also inform us about the reconfiguration/reproduction of power dynamics along regional lines. In the context of adopting reforms aimed at good territorial governance through the establishment of an advanced regionalization process, political parties boast about their selection criteria related to regionalization as a means to respect the spirit of the new Constitution. Regionalization means, on the one hand, representation of all regions on the national list; on the other hand, it means the decentralization of the procedure of candidates' selection as a way to ensure democratization. 
The notion of features that bring close the eligible candidates to those they are supposed to represent (Chraibi-Bennani, 2004) is less relevant in the case of the national list since candidates are not elected locally but are, rather, supposed to represent the common interests of the group of "women" as if "any woman can represent all women" (Mansbridge, 2005, p. 623). The complexity of the concept of representation as mirror ${ }^{4}$ makes the balance tip towards other criteria that legitimize the presence or the ranking order of candidates when the national list is in question.

If candidates of reserved seats fail to be political representatives with a real constituency, the issue of representation comes to the fore again through several concerns expressed by candidates and political leaders who focus on the importance of reflecting different sections that make up the Moroccan society.

Even if political parties pretend to set out rules governing the process of the selection of candidates, most of them give ambiguous definitions of the procedure and the criteria they adopt in order to nominate women on the national list. As stated also by James Liddell (2009), the Istiqlal Party and the PJD are the only parties to adopt a clear procedure for the selection of candidates on the national list. As far as the Istiqlal Party (IP) is concerned, regional representation was said to be the key element in the procedure followed by the IP to constitute its national list. The 16 regional councils were involved in carrying out the process of selection. The approach that distinguishes this party from others - sharing the same focus on regionalization - appears clearly in the internal guidelines on ranking adopted in the lists. Thus, the regions that achieved the best election results in $\mathbf{2 0 0 7}$ had the privilege to place their female candidates in better positions on national lists:

Previously, the procedure was quite different. The members of the national council of the party were those who voted, and the ranking was determined according to the number of votes obtained [...]. But now that the ranking has been influenced by the regional results of the 2007 legislative elections, the region of Marrakech has been poorly ranked. Within Marrakech's regional bureau, we chose Saida Bouâli without going through elections. She is the daughter of the late Ait Bouâli, ex-governor of Sidi Youssef Ben Ali and president of the local council, and a great activist. She has been a member of the party since an early age. We agreed to designate her without voting, but she was unfortunately outranked. All this has been done to push the regions to work better at local elections (MP 1 from the Istiqlal Party)..$^{5}$

Regional interests seem to be guilty of inhibiting the access of some "competent" women chosen democratically within regional branches to top positions on the national list. ${ }^{6}$ The national list acts as a tool to motivate political parties. That said, even when the procedure of nominating candidates is apparently clear, the public debate centres on a crucial factor, i.e. the extent to which reserved seats are instrumentalized to serve the political interests of a political party.

Central to the ongoing debate on regionalization as a criterion is the question of equal opportunity. It has been argued that the criterion of regionalization does not extend the representation beyond certain limits. Among the interviewees who criticized the making 
of the national list, some addressed the issue of over representation of some regions, especially the Saharan provinces that are given priority at the expense of others.

The procedure of the IP justifies the rank of M'kamaltou Kamal representing the Saharan region of Laâyoun Boujdour at the top of the national Istiqlal list and that of Zineb Kayouh, who is second, from the southern region of Souss Massa Daraâ. Even if the party itself cannot be held accountable because decisions related to ranking were made according to rules that are explicitly stated, some critics have accused the Istiqlal Party of deliberately using this procedure as a strategy to help those women they want to win.

The newspaper Essabah, for example, describes this procedure as a 'mined road map' (kharita malghouma) established under the pressure of strong lobbies within the party, in reference to the controversial debate between the two main "notables" of the party, Abdessamad Kayouh and Hamdi Ould Rchid, during the negotiations around the party nomination process. At the time, the former lobbied to place his sister, Zineb Kayouh, in the first position, and the latter did the same thing for his counsellor, M'kamaltou Kamal.

The PJD also advocates the representation of provinces on the national list: "We have chosen to set a balance so that this national list includes politicians, former MPs, the Sahara region, the MREs and also the technocrats," declared a member of the General Secretariat of the Justice and Development Party (PJD). ${ }^{7}$ In addition, it takes into consideration the representation of Moroccan residents abroad (MRA) on its national list, and placed Nezha El Ouafi third in the 2011 elections.

Even if quota women are not representatives of a given territory, political parties express their willingness to tie up representational functions to a geographical constituency within the framework of the process of advanced regionalization. The issue of accurate representation of the different regions has often been discussed by various researchers ${ }^{8}$ and is once again put in the spotlight throughout the debate around the criteria for appointing candidates to the national list.

Similar to the IP, other political parties have appointed candidates from southern regions on the highest positions of their national list without adopting a clear procedure for the nomination criteria. The Sahraouis Hasna Abouzaid and Rokaya Derham are second and fourth on the Socialist Union of Popular Forces (USFP) national list; the PJD placed Azzouha El Arrak fourth on its list. The over representation of the Saharan region has also been among the main issues under criticism during other elections. Frédéric Vairel describes the ranking of the Sahraoui Falla Boussoula as second on the national list of the USFP in 2002, of Khadija Hanine on the PJD list, and Zahra Cheggaf from the Popular Movement (MP) as first, as a "demonstration of commitment to the 'Moroccanity' of the Sahara" (Vairel, 2009, p. 147). Similarly, an MP from the party of USFP also noted the over-representation of the Sahara region in the 2011 elections: "There was just one representation of three or four regions. The Sahara region, for example, appears twice among the first positions, whereas one candidate from each region should be maintained. Among the top ten regions, only four are represented" (MP2, USFP). ${ }^{9}$ In fact, other interviewees argued that regional interests are to blame for inhibiting the access of "competent" women who are elected democratically on the national list. As they explained, 
women are instrumentalized, i.e. used as a tool of negotiations between the political parties and the community leaders affiliated to these parties. For instance, when a Sahraoui woman is placed on top of the list (due to regional interests), competent women are thereby negatively affected. Community leaders often ask to place their wives or other female relatives in an advantageous position on the national lists in exchange for favours to the parties.

The National List: A Negotiation Tool with "the Elite"?

As emphasized by Liza Baldez (2004), the quota system may introduce new players on the political scene who act according to the old rules. If the appointment of women is a man's affair, the quota system may seem "attractive" as it allows men to "choose malleable women not likely to challenge the patriarchal status quo" (Goetz \& Hassim, 2003, cited in Krook, 2008, p. 348).

The fact that political parties do not abide by specific rules to determine the candidates' ranking on their national lists may lead to "patronage" and bias the nomination process towards those candidates with connections and access to influential networks. Quotas are used to consolidate central party decisions (Baldez, 2004) and to reinforce the idea of parliaments as "patronage machines" (Liddell, 2009) by strengthening alliances with male candidates who are community leaders and other partners in order to serve the party's interests.

Several studies have shown the importance of integration into influential networks as an electoral strategy to gain legitimacy (Zaki, 2009; Bennani-Chraibi, 2004; Liddell, 2009). Gender quotas do not always succeed in questioning or breaking the patriarchal/ clientelist pressures which prevail through powerful families dominating the political scene (Sabbagh, 2007). The question we can ask, here, is the following: Is the national list instrumentalized to show loyalty to those in power in the party?

According to Liddell (2009, p. 84), "women with long records of party loyalty and service are passed over in favour of more influential and notable profiles." From this perspective, the procedure followed by the IP might be a good example of such a practice. Even if one of the interviewees from the Istiqlal Party does not agree with that statement, she recognizes that her party was blamed for "giving priority to spouses and daughters of party leaders" (MP 3 from IP). ${ }^{10}$

The issue of family connections pervades nearly all public debates on the quota that criticize the lack of formal procedures for selection and the fact that some candidates are used as proxies of their male relatives who are very often leaders within their parties. The fact that Fatima Tariq, the wife of Hamid Chabat, one of the party leaders and the general secretary of the Istiqlal Party, occupied the fourth position reminds us of a similar scenario involving former Istiqlal MP Abderrazak Afilal and his wife, Mahjouba Zoubir."1 Such combinations have been accused of favouring the selfreproduction of male elites through the nomination of female relatives.

One of the reasons for the dissatisfaction among USFP women ${ }^{12}$ is the prevalence of family ties and patronage, ${ }^{13}$ whereby some candidates inherit the political positions of their fathers or brothers. A case in point is the candidacy of Khadija Yamlahi (6th 
on the national list), who is the wife of Abdelhadi Khairat, member of the political office of the party and head of the USFP list in the Settat area. As can be read in the newspaper Soir échos:

What we found on these lists is that family ties prevailed at the expense of the established criteria with the Political bureau [...] Some names such as Rokaya Derham and Khadija Yamlahi, respectively placed in fourth and sixth positions on the national list, represented a controversial issue among women activists. ${ }^{14}$

The issue of family ties is a source of controversy in the party; there are those who denounce it as a sign of a patronage-based system and those who think that the family ties argument can work against women's effective struggle to enter the political field. In other words, accusing women MPs of establishing name recognition by virtue of their family relationships might reinforce the idea that male solidarity and support is the only way to women's presence in political positions.

Some activists justify the prevalence of family ties by the fact that politically influential families guarantee women sufficient exposure "to ideologies, know-how, and techniques to support them in their future political careers" (Sabbagh, 2007). Hence, they see no problem with a person, due to their family ties, having access to positions of responsibility if they are competent. Two interviewees from USFP and IP expressed their outrage at the accusation made against MPs who enter the political field by virtue of their family ties. According to one of the activists of the USFP, citing the case of Khadija Yamlahi:

She (Khadija Yamlahi) deserves to be an MP. There is no reason to disregard her just because her husband is a member of the Political Bureau. For fear of being charged with nepotism, Ms. Yemlahi was prevented from gaining access to the Political Bureau just because her husband is one of the party leaders. This woman was one of the first members of the national committee, which means one of the first MPs of the USFP, but she is not entitled to anything because of her family ties [...] You know, there are always some subjective criteria behind such choices (Batoul Badraoui, USFP). ${ }^{15}$

Another MP from the IP, who is highly ranked on the Istiqlal list, commented as follows:

I think that this criticism should not be generalized; it does not make sense because, in reality, these women are militants who stood for the internal elections at the regional level and some of them obtained the majority of votes. Of course this remark remains valid when it is linked to lack of qualifications and here again, unfortunately, as is the case everywhere in the world, we evaluate competencies only when women are concerned (MP 3, IP).

The Meaning of "Merit" as a Criterion of Selection Contemporary debates on gender quotas, even if concerned with how to fight discrimination while preserving 'merit' as a central criterion for candidate selection (Squires, 1996; Krook, 2009), have failed to question the nature of this 'merit'. Such a failure has masked the exclusion process within gender dynamics which tend to 
privilege certain groups over others in arbitrary ways (Krook, 2009). In spite of this failure, the debate is still ongoing whether women-only selections or "fast-track policies" are a violation of the principle of competitive equality.

The assertion that a woman is guaranteed a certain percentage among those elected "just because she's a woman" (Dahlerup, 2005) gives the impression that gender is the sole criterion for selection and that gender quotas suspend competition while, paradoxically, the question of "merit" and "competence" is very important, and women candidates are expected to compete with others (Matland, 2006).

It is worth noting that the competition around the nominations on the national lists has often mobilized the criterion of qualification or background in political activism or militancy (nidaliya in Arabic) to legitimize or delegitimize a candidacy. Such eagerness to adopt "merit" when it comes to female candidates is rooted in outdated discourses complaining about "the absence of competent women" eligible to stand for top positions (Belarbi, 2012). Moreover, it is "merit" as a substantial concept that becomes the subject of a continuous struggle for definition. It is sometimes associated with civil society activism, partisan activism, feminist activism, or seniority within the party. Indeed, the discourse of the interviewees is sprinkled with ideas referring to the criterion of militancy or political activism. In reality, the notion of militancy is justified through civil society activism or by presence in the highest bodies of the party - another stepping-stone or a necessary passage before entering Parliament.

\section{Civil Society Activism}

Some women placed in top positions on the national list have in fact displayed much involvement in civil activism. Naima Rebaâ, who runs the local branch of the IP in the Sidi Bernoussi neighbourhood in Casablanca, is ranked third on the national Istiqlal list. She is also best known for leading the NGO al-Amal in Sidi Moumen and the NGO Zenata for Development. Her engagement with activist NGOs won her the first place on the list of local elections as she demonstrated enough commitment working on the front lines and dealing directly with local communities. According to a woman activist from the IP,

Naima Rebaâ has provided outstanding leadership as an NGO president. She is well known in Sidi Moumen and Sidi Bernoussi and takes part in the most important party activities [...]. She is very much recognized within her party. ${ }^{16}$

Fouzia Lebied, who is third on the national list of the Constitutional Union (UC), is another civil society activist, founding member of al-Ounss for Development, Management, and Renewal (ADER) - a national NGO based in Dar Shabab in Ain Chock. This NGO, according to Lebied, had "played a vital role across local areas of Ain Chock". As she states herself, "I'm very close to the people".17

\section{Feminist Activism}

Feminist activism is another means through which candidates can aspire for a good ranking on the national list. Another MP, Jamila Mossali, second on the PJD list, holds a Ph.D. on feminist movements in Morocco and has been active in fighting for women's issues. Aicha Lakhmass, who occupies the top position on the USFP list, is 
also member of the USFP political bureau. Known for her feminist struggle, Lakhmass was director of the historical feminist journal 8 Mars from 1983 to 1995 and one of the instigators of the 1992 initiative of the One Million Signature Campaign to reform the moudawana (the Moroccan family code). She is president of the Women's Action Union and chair of "Annajd", which is a listening centre offering legal counselling for women victims of violence.

\section{Partisan Political Activism}

Activism within the party is another issue that makes the procedure of candidates' selection even more complex. While academic debates most often revolve around whether or not the gender quota is the best way to enhance women's presence in political positions, political activism or membership in the political bureau can sometimes offer unique access to parliament, bearing in mind that partisan activism has often been inextricably linked to women's parliamentary participation. Most of the women placed in the first positions on the national list occupy high-level party positions. In addition to Aicha Lakhmass, Fatna Lakhiel (head of the MP list), Rachida Benmasoud (USFP), Jamila Mossali, Bassima El Hakaoui (PJD), Bouchra Barijal, and Oum Lbanin Lahlou (UC), are all members of the political office of their parties.

In 2002, in the absence of a clear mechanism, the choice systematically fell on the two distinguished women of the PJD party, Bassima El Hakaoui and Soumaya Benkhaldoun, to be placed at the top of the national list. MP4 from PJD ${ }^{18}$ informed us that this choice was evident because the two women were both actively involved within the party. Bassima El Hakaoui, who was the only female member of the General Secretariat at the time, and Soumaya Benkhaldoun, who was a member of the regional secretariat of the party in Kenitra, were members of the Unity and Reform Movement (MUR) and were involved in civil activism.

The UC party, for example, placed the two female members of the political office at the head of its list. The first was Bouchra Barijal, a lawyer and poet from Nador who was placed at the top of the list, is president of the Liberal Forum of Art and Culture, vice-president on behalf of the UC of 'Internationale Libérale', and vice-president of the women's section of the party. ${ }^{19}$ The other member was Sabah El Mansouri from the Marrakech-Tensift Region.

The case of the Authenticity and Modernity Party (PAM) is quite special because it is a recent party. The majority of those placed at the head of the party's national lists are founding members of the PAM. Khadija Rouissi, second on the list, is President of the Ethics Commission within the party and President of Bayt Al Hikma. Bouchra Malki, who was third on the list, is a member of the National Executive and a university professor in Casablanca. Both of them are founding members of the party.

\section{The National List and the Challenge of the Renewal of Elites and Outgoing Women MPs}

The issue of reconciling "seniority" and political experience with "novelty" and openness to other sectors of society in order to promote generation renewal, regional balance, and adaptable alliances (Bennani-Chraibi, 2008) is taken into consideration while debating nomination criteria. Seniority is not always considered as a distinct 
advantage for candidates, and renewal of candidacies can sometimes be looked at as a practical strategy or a point of entry allowing for the dominance of patronage and clientelism. The issue of elite renewal has been the source of conflict within some political parties since 2007.

In 2007, when the USFP party proposed new candidates on its national list, it was accused of 'patronage ${ }^{\prime 20}$ and a few old militant members of the Party such as Aicha Belarbi, Rachida Benmassoud, ${ }^{21}$ and others withdrew from the national list ${ }^{22}$ to protest the downgrading or exclusion of women candidates who occupied top positions within the party. Malika Naciri, who is one of the founding members of the Front of Democratic Forces (FFD) Party, resigned from the party during the 2002 elections, because she was excluded from the national list. Nezha Skalli, downgraded from the first position in 2002 to the fourth position in 2011, wrote in her blog: "The head of the list Gajmoula has not yet celebrated her first birthday in the PPS [Party of Progress and Socialism] [...] Why not choose a militant from PPS?"23 One of the MPs from the UC Party evokes the experiences of 2002 and 2007 within her party:

In 2002, Mekouar was first on the national list while the second place was occupied by Khadija Mae El Aïnaïne, a Sahraoui responsible for the women's section in Marrakech. In 2007, those who were nominated on the national list wanted to participate again. Since the first two were not admitted, Mae El Ainaiine and two other women resigned from the political bureau of their party to protest against the ranking order. They believed firmly that as pioneer political activists, they should be prioritized and placed at the top of the list (MP 5, UC). ${ }^{24}$

The level of renewal has been tackled differently according to parties and has generated opposing views by women MPs and political leaders, especially after the introduction of Article 5 of Organic Law $n^{\circ}$. 27-11 establishing the principle of renewal, which was considered as a polemic move in this regard..$^{25}$ The Popular Movement party (PM) was, it seems, inflexible on this criterion: "We do not have any outgoing MPs on our national list. The Popular Movement is one of the first parties to have defended this point of view before the parliament" (MP 6, Popular movement) ${ }^{26}$

Some interviewees were against the idea of imposing this principle as a rule by which all political parties should abide. In response to this question, Abdelouahed Radi, the General Secretary of the USFP party, asserted:

It was difficult for us to refuse any candidacy. Each party has its limits and constraints. [...] some women MPs have acquired political expertise and excelled in doing their job as MPs. We would like to keep them. We should take into consideration the principle of renewal but not impose it as a general rule. ${ }^{27}$

The PAM has also included at the top of its list its former MP, Fatiha El Ayadi. Concerning the renewal of elites, El Ayadi stated that "this should not be decided by law; it's an internal matter for the party and should not be considered as law." She illustrated her opinion through examples:

I take the case of the party of National Rally of Independence (RNI), which ended 
up excluding one of its most brilliant women MPs, Mbarka Bouâyda, who at 35 years old is simply magnificent. She did a fabulous job as an MP but was excluded because of this issue of renewal and alternation. I shall give you also the case of the PJD, which appointed Bassima El Hakaoui and Jamila Mossali for the third time. And I think their performance was distinguished in the second term, precisely because they acquired experience from their first participation in parliament. ${ }^{28}$

Some interviewees supported seniority within the party as a criterion but insist upon the principle of renewal within the national list. Likewise, one of the interviewees from the USFP judged the ranking of the 2011 list as 'arbitrary' and denounced the absence of the pioneering women militants who have been involved within the party since the emergence of the Itihadi Women's Movement: "Some have given a lot to the party, they deserve their place among the top five, but this time they are not here".29 But, at the same time, she drew attention to non-compliance with the criterion of political 'alternation': "The outgoing women MPs should not return, but among the first ten on the national list, two former MPs are seeking another term in Parliament. The criterion of renewal and alternation was obviously not met".30

The issue of renewal has been less pronounced within other parties such as the PJD for which the degree of renewal has not been considered relevant or a strong predictor for nomination:

In our debate, seniority was rejected as a criterion from the beginning. Some have joined the party very recently but have been actively concerned with the party's issues, while others have been there for a long time without really being involved (MP 7, PJD). ${ }^{31}$

Even if seniority was not considered as an official criterion, the PJD opted for the nomination of three former MPs by renewing the candidacies of Nezha El Ouafi, Bassima El Hakaoui, and Jamila Mossali on the national list. The USFP's outgoing MPs were also counted among the first on the list:

There was a big problem and the Women National Council, after their meeting, decided that the MPs should not be represented on the national list but may run in some constituencies. As you can see, their decision has not been taken into consideration (MP 2, USFP).

One of the outgoing MPs, who was highly ranked on the national list, refused to run for another term. Her statements give a clear idea about the debates taking place around Article 5 of Organic Law $n^{\circ}$. 27-11, which establishes the principle of renewal:

This organic law could not get into parliament without prior agreement among the political parties. When Article 5 was presented inside the parties, it was not contested. This means that all the parties displayed the will to replace the outgoing MPs. In the parliamentary debate, the PJD has proposed no amendments to this article [...] this means that this party had the will to renew its outgoing MPs. Moreover, there were former MP lobbyists who wanted to stay. This lobbying didn't aim to remove Article 5 but only to introduce transitional provisions in Article 
97. Whereas this latter offers an exception to outgoing MPs to participate in 2011, in the case of our party, we said that it was not normal that we allow for ourselves what we do not for others. Rationally, following the same logic, the PJD was not supposed at all to nominate outgoing MPs (MP 4, PJD).

She also added:

I believe in the principle of renewing the elites, especially with respect to the national list. For the local list, there may be a few exceptions for some of the elected because we are a political party which should present only winning candidates. For more security, a party should try to win the maximum number of seats. In the case of the local lists, some names come back because they have a popular base and supporters. I criticized them. Whereas, at the national list, the problem does not arise because we know how citizens vote (MP4, PJD).

One of the MPs (MP 7, PJD) stated clearly that she wished that the candidates would not run repeatedly for election. She also criticized the parliamentarians who campaigned to neutralize Article 5 instead of campaigning for parity.

\section{The Transition to the District List ${ }^{33}$ : Between Patriarchy and Self- Responsibility}

While the national list is supposed to be a transitional and temporary mechanism to prepare women for the passage to the district lists, we note that some candidates do the opposite trajectory. Fatna Lakhiel, from the MP party and mayor of Arbawa elected twice on the district list, and Fatiha El Ayadi (PAM), elected on the district list of Ben Guerir, were head of the national list of their parties during the 2011 elections. The transition to the district list is a particularly good case study for assessing multi-level governance and central-regional controversies within political parties. Noteworthy are the conflicts that arise between regional and central branches of political parties around their rights to choose the candidates that will be placed in winning positions, i.e. by being placed in top positions on the list in order to win without the interference of central party organisations. ${ }^{34}$

This was the case in the negotiations that preceded the appointment of the head of PAM's national list:

Each region proposed a name. The decision was taken at the regional level except in the absence of a consensus where decisions returned to the central national level. The only area where there was a problem was that of Marrakech where my candidacy was not maintained. I submitted my candidacy to the regional council and was eliminated though I was a former MP and did not have any problems. The results given by the regional council were rejected at the central level. It is at this level that I was nominated and appointed head of the national list [...] There was no argument to justify my elimination (Fatiha El Ayadi, PAM).

Clearly, in the region of Marrakesh, the results of the deliberations of the Regional Elections Commission in charge of the nomination of candidates ended in a crisis. During the 2002 legislative elections, only five women succeeded in the challenge of 
competing in the district. None of the MPs elected through the national list in 2002 managed to win through the local district seat in 2007.

It is also worth noting that in 2007, five female MPs elected in the local constituencies belonged to the three conservative parties: the Istiqlal, the MP, and the PJD (Tel quel, no. 283, July 2007). In 2011, two candidates belonged to the PJD, ${ }^{35}$ one to the Istiqlal, one to the National Rally of Independence (RNI), and two to the new PAM party. ${ }^{36}$ In 2011, out of the seven women elected to district seats, only Yasmina Badou from the IP party had previous parliamentary experience (Darhour \& Dahlerup, 2013). These results offer evidence to support the 'glass ceiling theory' concerning the adoption of gendered quotas. As long as women get their share with reserved seats, the political parties abstain from selecting them for the district seats (Dahlerup, 2009).

Two kinds of justification are offered by interviewees when they are asked to explain this lack of transition from national to district lists (a transition considered legitimate since they won on the national list). One rests on the perception that holds men responsible for the situation, and the other one states that women are not involved as they should be in the process of district elections in the sense that they are not very enthusiastic about soliciting votes by campaigning in order to gain seats in local elections.

Both PJD interviewees said that everybody expected Bassima El Hakaoui ${ }^{37}$ to run for the Casablanca constituency but the General Secretariat did not propose her. Fatima Belahcen ${ }^{38}$ was not proposed for the district list either, added one of the interviewees, perhaps "because they think she would contribute more in the women union section" (MP 7, PJD). When asked to give the reasons behind women's refusal to nominate themselves on local lists for elections, one of the main figures of the PAM party admitted that the priority was given to men in those lists:

Yes, I thought I would participate at the district list of Rhamna that took place on the eve of the proclamation of the national list. What happened is that it was a little too tight. From the beginning, I said that I would run for the local list only if I am at the top of the list. There was another person, but she resigned and I was appointed head of the district list on the eve of the proclamation of the national list [...] In other words, you run for the national list, then, after two weeks, you are told 'We will find you a landing spot'. I think it is not serious. (Fatiha El Ayadi, PAM)

To conclude, a question should be asked regarding whether or not the quota enables women to achieve the goal of parity. The majority of the interviewees emphasized the transitional nature of the national list, aimed at helping women gain confidence, changing patriarchal mentalities, and encouraging men to vote for women or nominate them to the local lists:

The concept of the national list should be reviewed. Although we voted for parity in the constitution, we should avoid any form of discrimination. We cannot move from a temporary mechanism (aliya marhaliya) to an institutionalized one (tarsikh). When we triple the number of elected women on the national list from 30 to 90 , we are witnessing a consolidation of this temporary measure. But as long as this list exists, it will not allow the other 
women to move to the district list. In the subconscious of the parties, when the nomination committees get together they do not propose women because they think women have already their national list. (MP 7, PJD)

The Argument of Patriarchy In Morocco, the making of the national list was often seen as relying heavily on political parties and their leadership in the appointment of candidates (Liddel, 2009; Dahlerup, 2006, cited in Baydoun, 2009). If political parties are actually "good old boys networks" (Ballington, 2004) where women are marginalised as participants, and if party leaders are effective gatekeepers of parliamentary seats, several questions about the formation of the national list should be asked, mainly the extent to which the quotas reinforce the antidemocratic male centralization of the procedure for appointing candidates. As was noted by Liza Baldez (2004), the quota system may introduce new players on the political scene while ensuring that they play by the old rules. If the choice of women is men's business, the quota system can prove to be 'attractive', enabling men 'to select women' who are 'malleable' and unable to challenge the patriarchal status quo.

Aicha Belarbi affirms that "political parties do not open their doors to female candidacies on district lists". ${ }^{39}$ KhadijaYamlahi associates this attitude with a "patriarchal mentality", mentioning that "four women from our party presented their candidacies on the district list, but only three of them could run for local constituencies [...] they lack the support of their party".40

In addition to internal party structures and procedures which are blamed for being "patriarchal", another set of "patriarchal" factors are related to the electors/voters who are described as being still skeptical of women's abilities as political leaders. The underlying cultural prejudices and psychological barriers continue to prevent women from accessing the political arena and consequently from winning the trust of voters, hence discouraging them from trying to run on local lists.

What is the Women's Share of Responsibility?

The patriarchal argument may completely shift ${ }^{41}$ responsibility for the quasi-absence of women on district lists from women to men; however, women themselves find districts to be a difficult terrain to tread and believe men are better qualified because of their experience. One of the interviewees from the PJD (MP 7) confirms this assumption: "Jamila Mossali lives in Salé; she will not rival the Secretary General, Abdelilah Benkirane. Our candidates in Kenitra do not want to run for election in the same list of Rebbah".42 Sometimes women themselves internalize the "rules of the game" (Kandiyoti, 1988) set by male leaders or factions, reproducing at the same time the masculine structures inherent in patriarchal societies. When Fatima Tariq (IP) was asked to justify why she did not try to present her candidacy on the district list, she gave the following answer: "The simple reason is that my husband, Hamid Chabat, MP Mayor of the city of Fez, will present his candidacy. It will be abnormal if we both present our candidacies for the local constituencies of the same city".43 The fact that women are put in less favorable positions when they run for local constituencies was interpreted in many ways by interviewees. Some opinions used the argument of the "resource scarcity" (Ballington, 2004) to complain about the lack of resources required for women to organize on their own their campaigns, especially as political parties often choose 
to provide financial support to men who are more likely to win. In addition, allegations concerning women's lack of experience discouraged them from trying the district lists:

I believe that if women have a strong will, they will impose themselves anyway, and will be ready and prepared and supported by other women [...]. We had a case of one woman in the political bureau who wanted to be on the national list, but when she learnt that there were reservations about women previously elected through national lists to run for a second time, she decided at the last moment to present her candidacy on the district list, but she was not prepared. Women should work ahead of time and start their campaign much earlier (MP 8, USFP). ${ }^{44}$

Can we then conclude that district lists are still a male dominated field because the reserved seats do not allow women to acquire a power base? One of the MPs from the PAM party expressed her feelings of 'embarrassment' at the idea of running for a local constituency even if she was asked to by inhabitants:

If I want to run on a district list, I should have worked before with the people. But how can I aspire to run as a candidate on a local constituency if they never see me? [...] it will be difficult for me to convince them.

\section{Conclusion}

Despite the presence of clientelism in political practices, the competence argument is selectively applied to women (and not men) and is strongly evoked when women are concerned, when the men are not necessarily chosen for their qualifications. Women candidates on the national list are accused of 'tokenism' while all political mechanisms used by political parties are seen as practical strategies having a legitimate purpose to secure good results. Yet, little empirical research has shed light on some of the 'informal' practices that might hinder women's political advancement or'reproduce inequalities' within the scope of the quota's implementation. In fact, gender quotas are closely linked to deeper political reconfigurations that might accompany, from below, the implementation of quota processes. The procedures followed by political parties can uncover other aspects related to an internal party's organization, power dynamics, and other informal negotiations of political practices. One might ask the following question: Why is it so important to understand these internal informal practices and record all personal views related to them?

This study allows us to go beyond the approach that looks at gender quotas as a global phenomenon, exploring the personal views of women who are experiencing the process from inside. Discourses about what each one means by 'activism' contribute significantly to our knowledge of women's political representation and political elite formation. Listening to candidates' views about the criteria of selection and understanding why women are sceptical about district lists informs us about the way in which gendered discourses are reproduced and internalized.

Moroccan women resort to a justifying discourse through which they express their desire to be on the national electoral lists. In this case, gender is a system of categorization that is created and recreated on a daily basis (West \& Zimmerman, 1987). The national list appears to be a'gender factory' where the stratification of the feminine and masculine is 
displayed (Berk, 1985). Even if women have access to positions of political power, they continue sending out signals that show that they still have the impression of transgressing conventional gender expectations and react by resorting to such discourses. An analysis of discourses held by women politicians and widespread in the public debate allows one to look at gender quotas as the main sites of gender dynamics. The analysis of discourses shows how gender expectations trump women's access to inner circles of power.

Leila Bouasria is as an assistant professor at Hassan II University of Casablanca. She holds a PhD in Sociology from Mohamed V University in Rabat. Email: Ibouasria@gmail.com

\section{ENDNOTES}

1. The national list is a gender quota system that reserves a certain number of parliamentary seats for women who are elected on a list composed of only female candidates.

2. Some NGOs such as "La federation de la ligue démocratique pour les droits des femmes" (FLDDF) even considered resorting to the Constitutional Council to settle this issue.

3. Article 19 of the Constitution states: "Men and women have equal civil, political, economic, social, cultural, and environmental rights and freedoms as listed in this article and in the rest of the Constitution as well as the conventions and international treaties duly ratified by Morocco in conformity with the Constitution's provisions and the Kingdom's constants and its laws. The state shall work towards the establishment of parity between men and women. Therefore, it has assigned a specialized authority to ensure parity between men and women and fight against all forms of discrimination."

4. An interesting body of literature addresses the arguments in favour of the gender quota in relation to the issue of representation of women by women. Other opposing ideas affirm that this idea of representation goes against the principle of universal representation, which focuses on the representation of interests instead of identities (Bereni \& Lépinard, 2004). 5. Some interviewees (MP) who asked to stay anonymous are represented in this article by numbers ( 1 to 8$)$. Others are represented by their actual names. Some interviewees are not MPs but affiliated to political parties.

The interview with MP1 was conducted by Leila Bouasria on 10 October 2011.

6. This statement does not mean that the ranked candidates from other regions are less competent, but it gives an example of a situation in which regional interests limit the freedom of choice based on 'competence.'

7. Aujourd'hui le Maroc newspaper, 1 August 2007.

8. Maria Angustias Parejo (2002, cited by Bennani-Chraibi, 2004), shows that Rabat and Casablanca are the residences of three quarters of the elected MPs. Robert Rezette, in an earlier study on political parties, makes allusion to this imbalance in the regional representation within political parties. Amina El Messaoudi in her book, Ministers in the Moroccan Political System (2001), also shows how some regions are overrepresented at the expense of others.

9. Interview conducted by Leila Bouasria in December 2011.

10. Interview conducted by Leila Bouasria in October 2011.

11. Essabah newspaper, 4 November 2011.

12. See the article: “USFP: women militant do not see life in pink”, Le soir échos, 9 November 2011.

13. Le soir échos newspaper, 9 November 2011.

14. Le soir échos newspaper, 9 November 2011.

15 . I wish from my heart to pay tribute to the late Batoul Bardaoui who died in January 2015 and who was so kind to accept being interviewed for the present research in December 2011. She was known for her militancy and abnegation in the service of her country.

16. Interview conducted by Zakariya Agadid in November 2011.

17. Interview conducted by Leila Bouasria in November 2011.

18. Interview conducted by Leila Bouasria in October 2011.

19. Barijal submitted her candidacy on the 2007 list of the party but was not retained due to an adminis-trative error.

20. Moroccan weekly Magazine Tel quel, No. 286-285, August 2007.

21. Benmassoud was third on the 2011 list and was elected to the House of Representatives in 2002; she is also a university professor at Sidi Mohamed Benabdellah University. She is a novelist and author of several books, and she is member of the political bureau in her party. She was removed from the national 2007 list due to protesting her ranking (11th).

22. Mounia Bennani-Chraibi alluded to the opening of entrepreneurial and technocratic profiles. Among the top five on the 2007 national list were Salwa Kerkri Belkziz, ranked 11th on the 2011 list, who is President and General Director of GFI Morocco, and founder and honorary President of the AFEM (Association of Moroccan Women Entrepreneurs). Nezha Lahrichi, is another candidate who is an academic and consultant to the Prime Minister in 2005, and President and General Director of the Moroccan Society of Exports Insurance (SMAEX).

23. See www.nouzhaskalli.net

24. Interview conducted by Leila Bouasria in October 2011.

25. Article 5 of the organic law $n 27.11^{\circ}$ linked to the Chamber of representatives states: "Is considered ineligible for the 
House of Representatives, as part of the national local elections, any person who has been elected to the mentioned chamber under the mentioned constituency".

26. Interview conducted by Leila Bouasria in November 2011

27. Interview with Abdelouhaed Radi, Le Matin, 8 November 2011.

28. Interview conducted by Leila Bouasria in November 2011.

29. Interview conducted by Leila Bouasria in October 2011.

30. Interview conducted by Leila Bouasria in October 2011.

31. Interview conducted by Leila Bouasria in October 2011.

32. "The provisions of the 2 nd paragraph of Article 5 of this Organic Law does not apply to elections of members of the next House of Representatives to be held after the publication of this Organic Law in the Official Bulletin" (Article 97, Organic Law no. 27.11 on the House of Representatives passed on 14 October 2011).

33. In contrast to candidates nominated through the national list who are chosen by their parties, are accountable to them, and are supposed to represent women's rights and agendas at the national level, district list candidates are accountable to their voters as they run for election within a specific constituency. For more details about the procedure of elections, please see Darhour \& Dahlerup (2013).

34. This concern about the distribution of powers between the center and the local authorities was also one of the principle aspects of the constitutional recognition of the administrative autonomy.

35. The Board of the PJD adopted in 2007 a charter that encourages electing women candidates. Each candidate who runs a local list is entitled to a subsidy that ranges from 30,000 Dhs to 150,000 Dhs (3000 USD to 15000 USD). Women elected through the national list are required to repay a sum of $9000 \mathrm{Dhs}(900 \$)$ to the party, to be taken monthly from their parliamentary allowances, whereas this contribution varies between $6500 \mathrm{Dhs}(650 \$)$ and $7500 \mathrm{dhs}(750 \$)$ for the rest of the deputies. This sum may change on the basis of the degree of proximity to Rabat (Aujourd'hui le Maroc, 1 August, 2007).

36. Yasmina Baddou from the Istiqlal in Casa-Anfa constituency; two from the PAM: Jamila Afif in Gueliz Ennakhil and Fatima Ezzahra Mensouri in Sidi Youssef ben Ali; two from the PJD: laatimad Zahidi in Skhirate Temara and Souad Boulaich in Fahs Anjra, Tangier-Tetouan region; Souad Chaker Metalssi from the RNI party, Tangier.

37. Bassima El Hakkaoui is today the only female minister appointed in the new government led by the PJD Party.

38. In 2007, Fatima Belahcen passed from the district list to the national one. In 2002, she was the only one appointed by the PJD on a district list. She was elected in 2002 in the Beni Mekkada constituency in the region of Tangier. Her passage to the national list was justified by the new administrative division that split Tangier into two so that Beni Makkada became part of Fahs Anjra and no longer part of Tangier.

39. Interview conducted by Leila Bouasria, October 2011.

40. Interview conducted by Leila Bouasria, November 2011.

41. Women also take responsibility when it comes to the patriarchal argument that they can raise them-selves to explain their absence from the lists. I mean that not only men have these perceptions; even women themselves internalize them sometimes.

42. Abdelilah Benkirane is actually the Moroccan Prime Minister.

43. La Gazette du Maroc newspaper, 25 June 2007.

44. Interview conducted by Leila Bouasria On December 2011.

REFERENCES

Abou-zeid, G.(2006). The Arab region: Women's access to the decision-making across the Arab Nation. In D. Dahlerup (Ed.), Women, quotas, and politics (pp.168-193). New York: Routledge.

Bacchi, C. (2006). Arguing for and against quotas: Theoretical issues. In D.Dahlerup (Ed.), Women, quotas, and politics (pp. 32-51). New York: Routledge.

Baldez, L.(2004). Elected bodies: The gender quota law for legislative candidates in Mexico. Legislative Studies Quarterly, 24, 231-258.

Ballington, J. (2004). Strengthening internal political party democracy: candidate re-cruitement from a gender perspective. Stockholm: International IDEA.

Baydoun, A.C. (2009). Women in decision making positions: conditions and restraints. Al-Raida, 126-127, 53-57.

Belarbi, A. (2012). Egalité, parité, histoire inachevée, Casablanca, Le Fennec.

Bennani-Chraibi, M.(2004). Représenter et mobiliser dansl'élection législative au Maroc. In M. BennaniChraibi, M.Catusse \& J.C. Santucci (Eds.),Scènes et coulisses de l'électionau Maroc. Les legislatives 2002. (pp.15-53).Paris: Karthala.

Bennani-Chraibi, M. (2008), "Businessman" versus "universityprofessor," the parliamentarynotabilisation of a militant party in Morocco, La Revue Internationale de politique comparée, 15(2), 205-219.

Bereni, L.\&Lépinard, E. (2004), Les femmes ne sont pas une catégorie. Les stratégies de légitimation de la parité en France.Revue française de science politique, 54, 71-98.

Berk, S.F. (1985). The gender factory: The apportionment of work in American house-holds. New York: Plenum Press. 
Bozena, C.W.(2012). The strategic use of gender quotas in the Arab world. Washing-ton: IFES.

Caul, M.(2001). Political parties and the adoption of candidate gender quotas: A cross national analysis. Journal of Politics, 63, 1214-1229.

Childs, S. \&Krook, M.L.(2006). Should feminists give up on critical mass? A contingent yes. Politics \& Gender, 2, 522-530.

Dahlerup, D. (Ed.) (2006). Women, quotas, and politics. New York:Routledge.

Dahlerup, D. \&Nordlund, A.(2004). Gender quotas: A key to equality? A case study of Iraq and Afghanistan. European Political Science, 3,91-98.

Dahlerup, D. (2008). Gender quotas controversial but trendy: Onexpanding the research agenda. Stockholm: Stockholm University.

Darhour, H. \&Dahlerup, D. (2013). Sustainable representation of women through gen-der quotas: A decade's experience in Morocco. Women Studies International Forum. Retrieved April 13, 2014, from http://dx.doi.org/10.1016/j.wsif.2013.04.008

Darhour, H. \&Krit, S.D.(2012). Empowered or not? Moroccan women MP's strategies to empowerment. European Journal of Scientific Research, 77, 175-186.

El Messaoudi, A. (2001). Ministers in the Moroccan political system. Casablanca: Al Najah Al Jadida. (in Arabic)

El Messaoudi, A. (2011). Gouvernance et réalités électorales au Maroc: Les législatives 2007. In Essaid, J. (Ed.), Collection Réforme du droit et développement socio-économique, Dar Ennajah Eljadida, pp.153-178

Kandiyoti, D.(1988). Bargaining with patriarchy. Gender and Society, 2, 274-290.

Karam, A. (2000). Democrats without democracy: Challenges to women in politics in the Arab world. In Shirin Rai (Ed.), International perspectives on gender and democratization, women's studies at York, Basingstoke: MacMillan.

Kittilson, M.C. \&Fridkin, K. (2008). Gender, candidate portrayals and election cam-paigns: A comparative perspective, Politics \& Gender, 4,1-22.

Krook, M.L. (2006). Reforming representation: The diffusion of candidate gender quo-tas worldwide, Politics \& Gender, 2,302-327.

Krook, M.L. (2007). Candidate gender quotas: A framework for analysis.European Journal of Political Research, 46, 367-394.

Krook, M.L. (2008). Social politics: International studies in gender, state and society, Volume $15, N^{\circ} 3$, Fall 2008, PP.345-368.

Krook, M.L.(2009). Quotas for women in politics: Gender and candidate selection re-form worldwide. New York: Oxford University Press.

Liddell, J.(2009).Gender quotas in clientelist systems: The case of Morocco's national list. Al-Raida, 126$127,79-86$.

Mansbridge, J. (2005). Quota problems: Combating the dangers of essentialism. Politics \& Gender, 1, 622638.

Matland, R.(2006). Electoral quotas: Frequency and effectiveness, in D. Dahlerup (Ed.), Women, quotas and politics (pp. 275-292).New York: Routledge.

Matland, R. (2008). Enhancing women's political participation: legislative recruitment and electoral systems. International IDEA, Women in parliament: Beyond numbers, IDAA: Stockholm.

Murray, R.(2004). Why didn't parity work? A closer examination of the 2002 election results. French Politics, 2, 347-362.

Sabbagh, A. (2007). Overview of women's political representation in the Arab region: Opportunities and challenges. The Arab quota report: Selected case studies (pp. 7-18). Quota report series. Stockholm: International Institute for Democracy and Electoral Assistance.

Sater, James N.(2007).Changing Politics from Below? Women Parliamentarians in Morocco. In Democratization 14 (4), 723-742.

Sater, N. James. (2012). Reserved Seats, Patriarchy, and Patronage in Morocco. In: The impact of Gender Quotas, Franceschet, Susan. et al (eds). OUP: NY. P. 72-88.

Squires, J. (1996).Quotas for women: Fair representation? In Lovenduski, J. \&Norris, P. (Eds), Women in politics. New York: Oxford UniversityPress.

Vairel, F.(2009). La liste nationale: Un quota électoral pour quoi faire? In Zaki, L. (Ed.), Terrains de campagne au Maroc. Les élections législatives de 2007. Paris: Karthala.

Zaki, L. (Ed.), (2009). Terrains de campagne au Maroc. Les élections législatives de 2007. Paris: Karthala. West, C.\& Zimmerman, D. (1987). Doing gender. Gender, and Society, 1(2), 125-151. 
Tables

Table 1. The Affiliation of Interviewees

\begin{tabular}{|l|l|}
\hline \multicolumn{1}{|c|}{ Political Affiliation } & \multicolumn{1}{c|}{ Number of Interviewees } \\
\hline USFP & 3 \\
\hline UC & 4 \\
\hline PJD & 3 \\
\hline PAM & 2 \\
\hline IP & 3 \\
\hline MP & 2 \\
\hline Total & 17 \\
\hline
\end{tabular}

Table 2. Acronyms

\begin{tabular}{|l|l|l|}
\hline \multicolumn{1}{|c|}{ Name of the party } & \multicolumn{1}{|c|}{ Abbreviation } & \multicolumn{1}{c|}{ Ideology } \\
\hline $\begin{array}{l}\text { Socialist Union of Popular } \\
\text { Forces }\end{array}$ & USFP & Conservatism, nationalism \\
\hline Independence Party & IP & Islamism \\
\hline $\begin{array}{l}\text { Justice and Development } \\
\text { Party }\end{array}$ & PJD & Liberalism, nationalism \\
\hline Popular Movement & MP & Socialism \\
\hline $\begin{array}{l}\text { Party of Progress and So- } \\
\text { cialism }\end{array}$ & PPS & Conservatism, liberalism \\
\hline $\begin{array}{l}\text { Authenticity and } \\
\text { Modernity Party }\end{array}$ & PAM & Conservatism, liberalism \\
\hline Constitutional Union & UC & Liberalism \\
\hline $\begin{array}{l}\text { National Rally of } \\
\text { Independence }\end{array}$ & RNI & Socialism \\
\hline Front of Democratic Forces & FFD & \\
\hline
\end{tabular}

Table 3. Election Results of 2011 National List

\begin{tabular}{|l|l|}
\hline \multicolumn{1}{|c|}{ Political Party } & \multicolumn{1}{c|}{ National List (women) } \\
\hline PJD & 16 \\
\hline PI & 9 \\
\hline USFP & 6 \\
\hline RNI & 8 \\
\hline PAM & 8 \\
\hline MP & 5 \\
\hline UC & 4 \\
\hline PPS & 4 \\
\hline Total & 60 \\
\hline
\end{tabular}


Table 4: Profile Glossary

\begin{tabular}{|c|c|}
\hline Names & Profile \\
\hline Zineb Kayouh & $\begin{array}{l}\text { Zineb Kayouh is the daughter of Haj Ali } \\
\text { Kayouh, the Istiqlalian notable and MP } \\
\text { from Souss. She is the sister of Abdessamad } \\
\text { Kayouh, an MP from an Istiqlalian family } \\
\text { and former minister of 'Artisanat.' She is a } \\
\text { businesswoman, ranked 13th on the } 2007 \\
\text { list. She is member of the National Board, the } \\
\text { Executive Committee, the Istiqlalian women's } \\
\text { organization, and of the local council of } \\
\text { Ouled Tayma in Agadir. }\end{array}$ \\
\hline M'kamaltou Kamal & $\begin{array}{l}\text { M'kamaltou Kamal joined the Istiqlal } \\
\text { Party, coming from the USFP Party. She is } \\
\text { a Sahraoui from the Ait Lahcen tribe, an } \\
\text { officer at the Ministry of Health of Laâyoune, } \\
\text { a CORCAS member (Royal Advisory } \\
\text { Council for Saharan Affairs), chairwoman } \\
\text { of the Istiqlalian women's organization in } \\
\text { Laâyoune, counselor of Hamdi Ouled Rachid, } \\
\text { and President of the CORCAS. }\end{array}$ \\
\hline Nezha el-Ouafi & $\begin{array}{l}\text { Member of the MRA and former deputy } \\
\text { of the party, she is the only deputy in the } \\
\text { country residing abroad and coordinator of } \\
\text { the Coalition MRE (CMRE), an association } \\
\text { involving } 180 \text { organizations representing } \\
\text { the Moroccan diaspora abroad. She is also a } \\
\text { board member of the National Labour Union } \\
\text { (UNTM). }\end{array}$ \\
\hline Azzouha el-Arrak & $\begin{array}{l}\text { She is an engineer who represents the } \\
\text { Saharan region of Oued Ed-Dahab Legouira. }\end{array}$ \\
\hline Hassna Abou Zayd & $\begin{array}{l}\text { Hassna Abu Zayd, ranked second on the } \\
\text { list of the USFP, is from Dakhla. She is a } \\
\text { pharmacist and a member of the National } \\
\text { Secretariat of USFP Women. }\end{array}$ \\
\hline Rokaya Derham & $\begin{array}{l}\text { The fourth on the list is Rokaya Derham, } \\
\text { Hassan Derham's niece and daughter of } \\
\text { Feydoul Derham. Driss Lachguer, the General } \\
\text { Secretary of the USFP, who introduced } \\
\text { the candidate in a gathering organized } \\
\text { in Derham's family home, stated: "She } \\
\text { embodies the continuation of activism } \\
\text { that characterizes the Derham family since } \\
\text { the Spanish colonization and through the } \\
\text { independence of the Sahraoui provinces." }\end{array}$ \\
\hline
\end{tabular}




\begin{tabular}{|c|c|}
\hline Fatima Tariq & $\begin{array}{l}\text { She is the wife of the general secretary of the } \\
\text { Istiqlal party and a member of the central } \\
\text { committee of the IP. }\end{array}$ \\
\hline Abderrazak Afilal & $\begin{array}{l}\text { The former Secretary General of the General } \\
\text { Union of Moroccan Workers (UGTM). }\end{array}$ \\
\hline El Hajja Mahjouba Zoubir & $\begin{array}{l}\text { The wife of Abderrazak Afilal. She was } \\
\text { elected in } 2002 \text { and occupied the third } \\
\text { position in the list; she is also an NGO } \\
\text { activist. }\end{array}$ \\
\hline Khadija Yamlahi & $\begin{array}{l}\text { She is a professor, member of the USFP } \\
\text { Women National Secretariat, and coordinator } \\
\text { of the women's section of the party. }\end{array}$ \\
\hline Fouzia Lebied & $\begin{array}{l}\text { She holds a Ph.D. in French Literature and a } \\
\text { B.A. in Public Law. She is a former journalist } \\
\text { with Albayane and Libération newspapers. }\end{array}$ \\
\hline Jamila Mossali & $\begin{array}{l}\text { Jamila Mossali is an MP from Salé since } \\
\text { 2002. She is also Chair of the Moroccan- } \\
\text { Venezuelan Parliamentary Friendship Group } \\
\text { at the Parliament and Director of al-Wiam } \\
\text { center, which works to improve the status } \\
\text { of women. Jamila Mossali is an academic } \\
\text { specializing in feminism. She is President } \\
\text { of the National Committee of Women and } \\
\text { Family in her party (PJD). }\end{array}$ \\
\hline Bassima el-Hakkaoui & $\begin{array}{l}\text { El-Hakkaoui is President of the Revival of } \\
\text { Female Consciousness Organization and } \\
\text { Benkhaldounis President of Mountada } \\
\text { Ezzahrae. }\end{array}$ \\
\hline Fatiha el-Ayadi & $\begin{array}{l}\text { She is a journalist and former } \\
\text { communication consultant in the Ministry of } \\
\text { Culture. She is the youngest daughter of el- } \\
\text { Ayadi, a former qaid (tribal governor) in the } \\
\text { region of Rhamna. }\end{array}$ \\
\hline
\end{tabular}

